\title{
Vertebrate phenology at similar latitudes: temperature responses differ between Poland and the United Kingdom
}

\author{
Tim Sparks ${ }^{1, *}$, Piotr Tryjanowski ${ }^{2}$, Arnold Cooke ${ }^{3}$, Humphrey Crick $^{4}$, \\ Stanislaw Kuźniak ${ }^{2}$ \\ ${ }^{1}$ Natural Environment Research Council (NERC) Centre for Ecology and Hydrology, Monks Wood, Abbots Ripton, \\ Huntingdon, Cambridgeshire PE28 2LS, UK \\ ${ }^{2}$ Department of Behavioural Ecology, Adam Mickiewicz University, Umultowska 89, 61-614 Poznan, Poland \\ ${ }^{3} 13$ Biggin Lane, Ramsey, Huntingdon, Cambridgeshire PE26 1NB, UK \\ ${ }^{4}$ British Trust for Ornithology, The Nunnery, Nunnery Lane, Thetford, Norfolk IP24 2PU, UK
}

\begin{abstract}
We examined the phenology of 2 amphibians (common frog Rana temporaria, common toad Bufo bufo) and one resident bird species (blackbird Turdus merula) at locations in Poland and in the UK on similar latitudes. The timing of phenology was earlier in the UK than in Poland, presumably as a consequence of a warmer maritime environment. This was further confirmed by the earlier frog spawn phenology in the warmer west of the UK than in the east. In the amphibians, the response to temperature was significantly greater in the UK than in Poland, although for the resident bird species the greater response in the UK did not achieve significance. These results suggest that species are adapted to local conditions. However if such adaptive strategies are not able to evolve rapidly to match rapidly changing climatic conditions, then severe disruption to the least flexible elements in any system may result.
\end{abstract}

KEY WORDS: Rana temporaria • Bufo bufo . Turdus merula . Temperature response rate . Climate change $\cdot$ Egg-laying $\cdot$ Spawning

\section{INTRODUCTION}

In an earlier study, Tryjanowski et al. (2006) reported on the differential phenological response to temperature between a location in Poland and one in the UK for 2 plant species, the woodland forb Viola reichenbachiana and the ornamental tree Aesculus hippocastanum. Because the 2 locations were at similar latitudes they would have very similar light regimes (photoperiod), so the differences they reported in temperature response seem to be the consequence of local selection or genetics. It is clear that animals, directly or indirectly, follow vegetation development and also respond to temperature (Tryjanowski et al. 2002, Walther et al. 2002, Cummins 2003, Parmesan \& Yohe 2003, Rainio et al. 2006). However, to our knowledge, there has not been an analysis which focuses on the response of animals to temperature at similar latitudes but under contrasting climate regimes. Because amphibians and birds are often used in phenological studies (Walther et al. 2002, Parmesan \& Yohe 2003) we decided to use data on spring activity and/or spawning date of 2 amphibians: the common frog Rana temporaria and the common toad Bufo bufo, and egg-laying date of one bird-the blackbird Turdus merula. All 3 are sedentary species, therefore we predicted that the effect of local temperature should be stronger than for long-distance migratory species (Tryjanowski et al. 2002, Parmesan \& Yohe 2003, Raino et al. 2006). We expected that any difference in response between amphibians and birds should be connected to the different role that temperature plays in determining the 
phenology of these animals. Because amphibians are sedentary ectothermic (cold blooded) animals and because they are sensitive to changes in local ambient temperature, subtle changes in climate may be reflected in changes in timing and duration of their hibernation and breeding activity. The blackbird, whilst sedentary, is more mobile than the 2 amphibians and may therefore change its wintering place according to the local temperature/food situation.

We extend the earlier study and examine phenological responses in the reproduction of 1 endothermic (warm blooded) and 2 ectothermic vertebrates. We use data on first spawning, migration and laying dates, because these are readily available and have been found to be robust in previous analyses of phenology (Sparks et al. 2001).

\section{MATERIALS AND METHODS}

First observation dates of spawning by common frog Rana temporaria for 1978-2005 were collected from 3 locations; the environs of the village of Turew in Poland (centred on ca. $52.1^{\circ} \mathrm{N}, 16.8^{\circ} \mathrm{E}$; Tryjanowski et al. 2003), Huntingdonshire (now part of Cambridgeshire) in eastern England (centred on ca. $52.4^{\circ} \mathrm{N}$, $\left.0.1^{\circ} \mathrm{W}\right)$ and the village of Kilgetty in Wales $\left(51.7^{\circ} \mathrm{N}\right.$, $4.7^{\circ} \mathrm{W}$ ). Records for Turew, sited within an arable landscape, were taken within $5 \mathrm{~km}$ of the village. Huntingdonshire is an area of $950 \mathrm{~km}^{2}$ in a largely arable landscape. Records for Kilgetty were taken on a farm in a pastoral landscape. All sites are at altitudes under $100 \mathrm{~m}$ above sea level (a.s.l.). First spawning dates of common toad Bufo bufo in Turew were obtained for the same years as for frogs (Tryjanowski et al. 2003). We could not obtain toad spawning records for a similar latitude in the UK, so we used dates when peak numbers of traffic casualties were recorded each spring, 1978-2005, on roads within $250 \mathrm{~m}$ of the breeding pond at Field Road, Ramsey, Cambridgeshire $\left(52.5^{\circ} \mathrm{N}, 0.1^{\circ} \mathrm{W}\right.$; Cooke \& Sparks 2004). The peak traffic casualty dates were when peak migration into the pond had just occurred and are expected to approximate breeding dates. At a nearby colony, where both migration and spawning were recorded for $11 \mathrm{yr}$, first spawning was (on average) a few days earlier than, and highly correlated $(\mathrm{p}<0.001)$ with, peak migration date.

Records of first-egg laying dates in blackbird Turdus merula nests were obtained from Leszno in Poland (centred on ca. $51.8^{\circ} \mathrm{N}, 16.6^{\circ} \mathrm{E}$ ) and from eastern England (centred on ca. $52.4^{\circ} \mathrm{N}, 0.8^{\circ} \mathrm{E}$ ) from the British Trust for Ornithology's Nest Record Scheme (Crick et al. 2003). For each country the earliest of the first egg dates (FED) and the number of nest records for each year from 1978-2004 were extracted. In both cases, the available datasets are part of a random selection of the records computerised for national monitoring purposes and the number of records varied greatly; Poland from 2 to 17 records annually (average 7), England from 1 to 33 records annually (average 17). The number of records affects the minimum FED in a nonlinear way; for England the correlation between minimum FED and sample size was -0.37 ; that with log sample size -0.51 ; thus the analyses below use log sample size to control for the number of records.

Mean monthly temperatures for the Polish series were obtained from the Turew meteorological station (ca. $30 \mathrm{~km}$ from Leszno) and for the English series from the Central England temperature series (www. metoffice.gov.uk/research/hadleycentre/obsdata/cet. html). Because the Welsh site is close to the western coast of the UK, the Central England record may not be representative here, particularly in winter (Croxton et al. 2006). Consequently, we obtained temperature data from Aberporth meteorological station (ca. $45 \mathrm{~km}$ distant; $52.1^{\circ} \mathrm{N}, 4.5^{\circ} \mathrm{W}$ ) to compare with data from Kilgetty.

Trends in phenology were assessed by regression on year to examine for changes over time; those for blackbird FED were assessed after first fitting log sample size. Temperature responses were examined by regression of phenology on the mean temperature of an antecedent 3 mo period; for blackbird (after fitting log sample size) using February-April means; for Polish and English amphibians using January-March means and for Welsh frogs using November-January means. Antecedent periods of 3 mo have previously been shown to account for most of the phenological temperature response (Menzel et al. 2006). Equality of slopes was compared using standard regression techniques (Draper \& Smith 1998).

\section{RESULTS}

All of the 3 mo temperature periods we have used for the UK experienced a significant increase in temperature, but neither of the 2 Polish periods did so (Table 1).

Table 1. Mean temperatures $( \pm \mathrm{SD})$, temporal temperature trends $\left(b_{;} \pm S E\right)$ and significance of these trends $(p)$ for November-January (NDJ), January-March (JFM) and February-April (FMA) 1978-2005 (28 yr)

\begin{tabular}{|llccl|}
\hline Period & Location & Temperature $\left({ }^{\circ} \mathrm{C}\right)$ & $\mathrm{b}\left({ }^{\circ} \mathrm{C} \mathrm{yr}^{-1}\right)$ & $\mathrm{p}$ \\
\hline NDJ & Wales & $6.4 \pm 0.8$ & $0.037 \pm 0.017$ & 0.032 \\
$\mathrm{JFM}$ & Poland & $1.0 \pm 2.2$ & $0.053 \pm 0.053$ & 0.32 \\
& England & $5.0 \pm 1.4$ & $0.092 \pm 0.028$ & 0.003 \\
FMA & Poland & $4.2 \pm 1.6$ & $0.037 \pm 0.037$ & 0.33 \\
& England & $6.4 \pm 1.1$ & $0.079 \pm 0.022$ & 0.022 \\
\hline
\end{tabular}


Table 2. Rana temporaria, Bufo bufo and Turdus merula. Frog and toad spawning and migration dates, and blackbird first egg date in Poland, England and Wales. L: length of measuring period (yr); mean dates also given as DOY: day of year (mean $\pm \mathrm{SD})_{i}$ b: temporal trends $( \pm \mathrm{SE})_{i}$ p: significance of temporal trends. Trends for blackbird were examined sequentially after fitting log sample size

\begin{tabular}{|c|c|c|c|c|c|}
\hline & L (yr) & Mean date & DOY & $\mathrm{b}\left(\mathrm{d} \mathrm{yr}^{-1}\right)$ & $\mathrm{p}$ \\
\hline \multicolumn{6}{|l|}{$\begin{array}{l}\text { Frog } \\
\text { spawning }\end{array}$} \\
\hline Poland & 22 & 30 Mar & $89 \pm 5.3$ & $-0.23 \pm 0.13$ & 0.082 \\
\hline England & 28 & $4 \mathrm{Mar}$ & $63 \pm 11.6$ & $-0.41 \pm 0.27$ & 0.13 \\
\hline Wales & 23 & 25 Jan & $25 \pm 6.7$ & $0.12 \pm 0.19$ & 0.54 \\
\hline \multicolumn{6}{|l|}{$\begin{array}{l}\text { Toad } \\
\text { spawning }\end{array}$} \\
\hline Poland & 21 & $8 \mathrm{Apr}$ & $98 \pm 4.8$ & $-0.32 \pm 0.10$ & 0.004 \\
\hline \multicolumn{6}{|l|}{$\begin{array}{l}\text { Toad } \\
\text { migration }\end{array}$} \\
\hline England & 28 & 25 Mar & $84 \pm 14.6$ & $-0.74 \pm 0.32$ & 0.027 \\
\hline \multicolumn{6}{|l|}{$\begin{array}{l}\text { Blackbird } \\
\text { first egg }\end{array}$} \\
\hline Poland & 27 & 17 Apr 1 & $107 \pm 12.7$ & $-0.14 \pm 0.24$ & 0.57 \\
\hline England & 27 & 22 Mar & $81 \pm 12.6$ & $-0.64 \pm 0.28$ & 0.030 \\
\hline
\end{tabular}

\subsection{Frog}

None of the trends in the first spawning of frogs was significant (Table 2, Fig 1), although that from Poland was marginally significant $(p=0.082)$. Mean dates from all 3 sites were significantly different from one another (assessed by Tukey's test, following 2-way ANOVA $\left.F_{2,43}=430.95, \mathrm{p}<0.001\right)$, but there was no significant difference in trends over time $\left(F_{2,67}=1.45, \mathrm{p}=\right.$ 0.24). Spawn dates in Wales were particularly early. There was a significantly greater variability in spawn dates in England than at the other 2 sites (Variance Ratio tests, $\mathrm{p}<0.005)$. The 3 sites had significantly different temperature responses $\left(F_{2,67}=4.63, \mathrm{p}=0.013\right)$ (Table 3, Fig. 2), UK responses being greater than

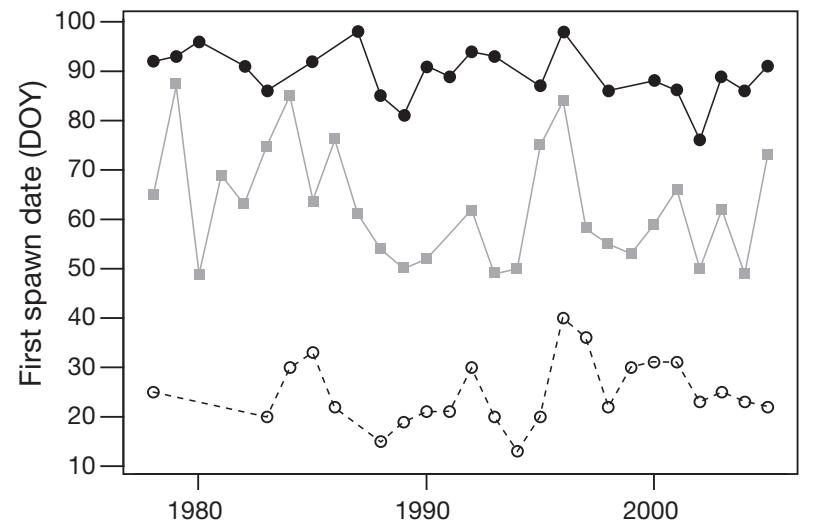

Fig. 1. Rana temporaria. Trends in first spawning dates (day of year, DOY) of frog in Poland (black), England (grey) and Wales (dashed)
Table 3. Rana temporaria, Bufo bufo and Turdus merula. Response $(b ; \pm S E)$ and significance of response $(p)$ of frog and toad spawning and migration dates, and of blackbird first egg date, to temperatures during 3 mo periods (JFM: JanuaryMarch; FMA: February-April; NDJ: November-January). Responses for blackbird were examined sequentially after fitting log sample size

\begin{tabular}{|lccc|}
\hline & Period & $\mathrm{b}\left(\mathrm{d}^{\circ} \mathrm{C}^{-1}\right)$ & $\mathrm{p}$ \\
\hline Frog spawning & & & \\
Poland & $\mathrm{JFM}$ & $-1.40 \pm 0.37$ & 0.001 \\
$\begin{array}{l}\text { England } \\
\text { Wales }\end{array}$ & JFM & $-4.94 \pm 1.31$ & 0.001 \\
Toad spawning & NDJ & $-3.55 \pm 1.72$ & 0.052 \\
$\begin{array}{l}\text { Poland } \\
\text { Toad migration }\end{array}$ & $\mathrm{JFM}$ & $-0.82 \pm 0.43$ & 0.075 \\
$\begin{array}{l}\text { England } \\
\text { Blackbird first egg }\end{array}$ & $\mathrm{JFM}$ & $-6.95 \pm 1.53$ & $<0.001$ \\
$\begin{array}{l}\text { Poland } \\
\text { Wales }\end{array}$ & FMA & $-2.50 \pm 1.04$ & 0.024 \\
& FMA & $-3.84 \pm 1.83$ & 0.047 \\
\hline
\end{tabular}

those from Poland. Temperature response in England may have been accentuated, because the frog increased markedly in abundance during the study period (Cooke 1999) and so bred at many more sites during the recent mild springs. The relative high winter temperatures-and hence early spawn dates-in Wales are evident from Tables $1 \& 2$ and Fig. 2.

\subsection{Toad}

Toad peak migration in the UK was significantly earlier than first spawn date in Poland (paired $t_{20}=-5.09$, $\mathrm{p}<0.001$ ) (Table 2, Fig. 3) and significantly more variable (Variance Ratio test, $\mathrm{p}<0.001$ ). There was a sig-

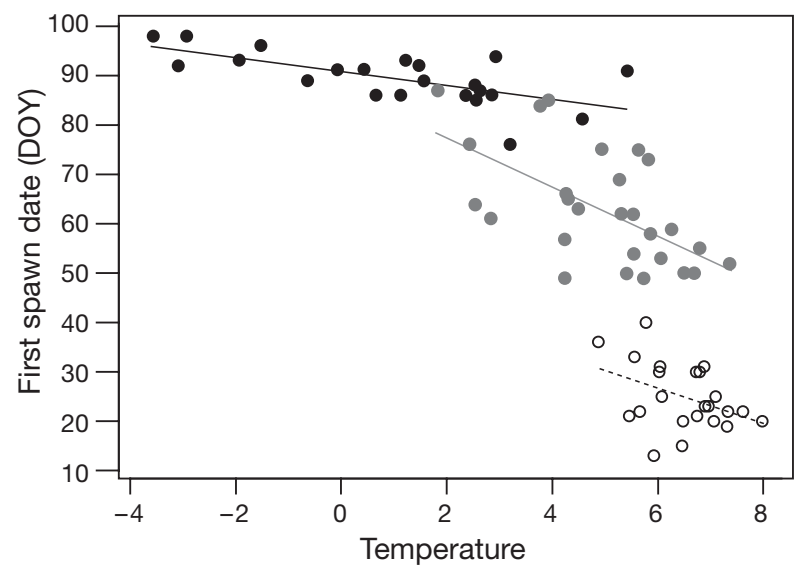

Fig. 2. Rana temporaria. Relationship between first spawning dates (day of year, DOY) of the common frog in Poland (black) and in England (grey) with January-March mean temperature, and in Wales (dashed, open symbols) with November-January mean temperature $\left({ }^{\circ} \mathrm{C}\right)$ 


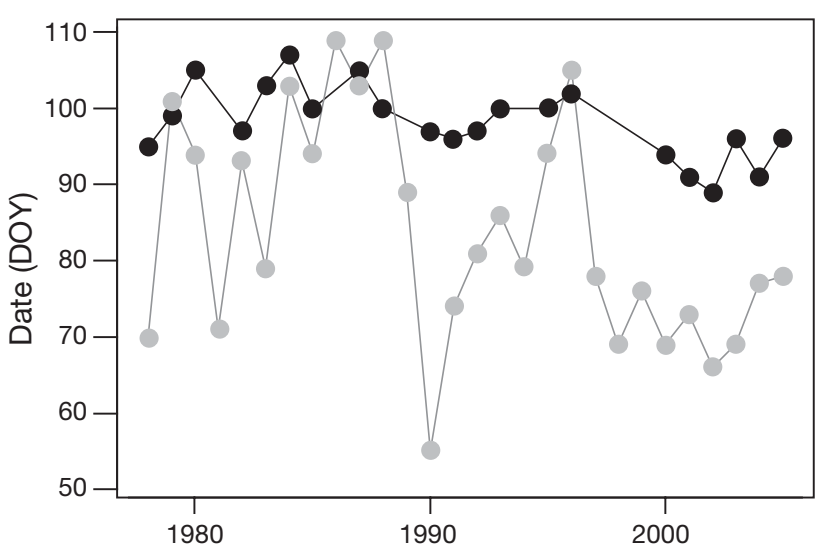

Fig. 3. Bufo bufo. Trends in first spawning dates (day of year, DOY) of common toad in Poland (black) and peak migration dates in England (grey)

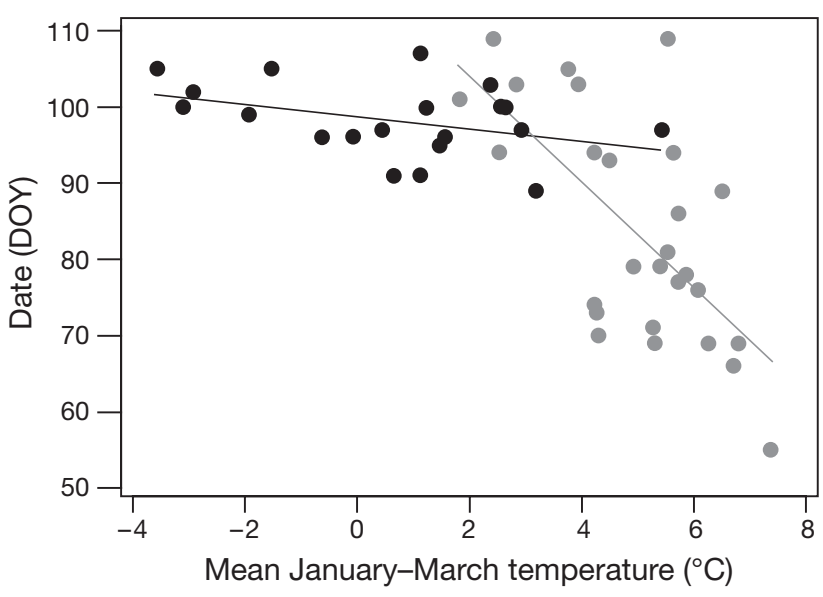

Fig. 4. Bufo bufo. Relationship between first spawning dates (day of year, DOY) of the common toad in Poland (black) and peak migration dates in England (grey) with January-March mean temperature $\left({ }^{\circ} \mathrm{C}\right)$

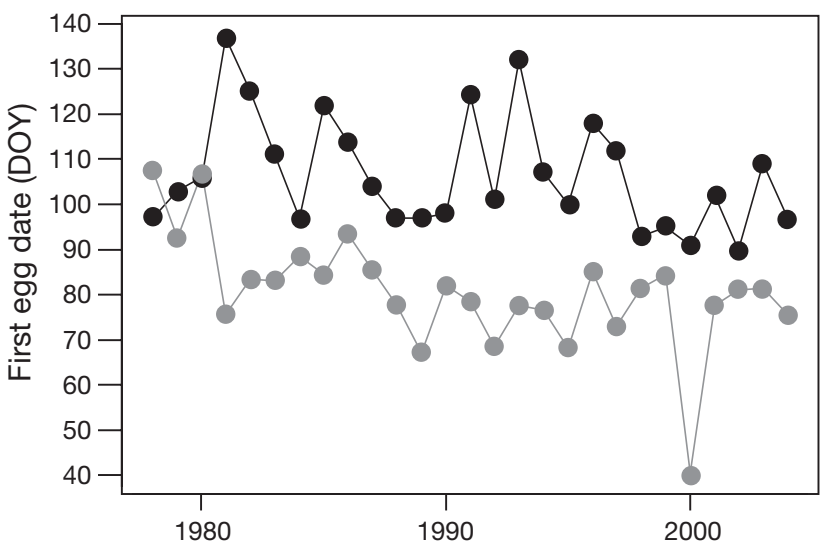

Fig. 5. Turdus merula. Minimum first egg dates (day of year, DOY) of blackbird in Poland (black) and England (grey) for 1978-2004

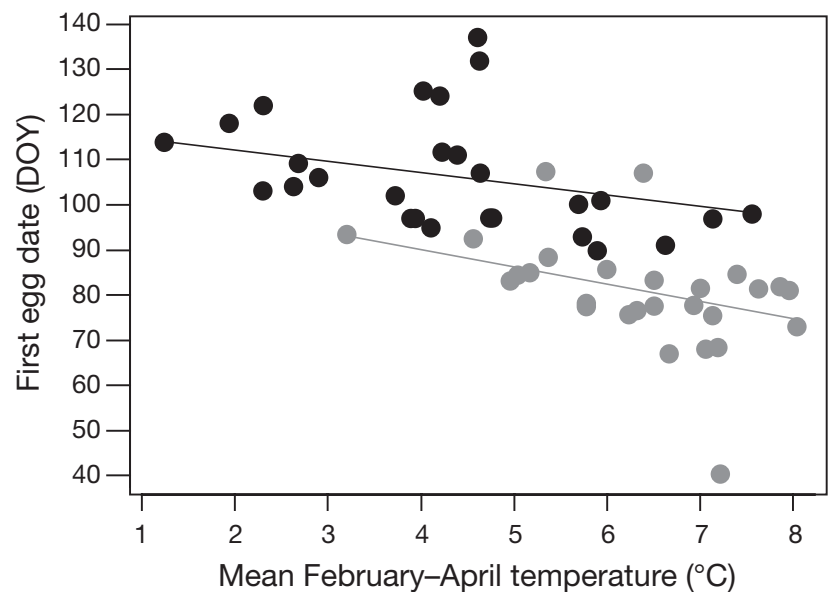

Fig. 6. Turdus merula. Minimum first egg dates (day of year, DOY) of blackbird in Poland (black) and England (grey) in relation to mean February-April temperature $\left({ }^{\circ} \mathrm{C}\right)$

nificant advance in the dates for both toad records (Table 2), but no significant difference in the trend between the 2 sites $\left(F_{1,45}=1.30, \mathrm{p}=0.26\right)$. Both toad records showed evidence of a response to temperature, although the response in Poland was only marginally significant $(p=0.075)$ (Table 3$)$. Responses to temperature were significantly different $\left(F_{1,45}=16.79, \mathrm{p}<\right.$ 0.001) (Fig. 4).

\subsection{Blackbird}

Mean minimum FED for blackbird was $26 \mathrm{~d}$ earlier in England than in Poland (paired $t_{26}=-8.03, \mathrm{p}<0.001$ ) (Table 2). Trends in minimum FED for blackbird are shown in Fig. 5. After fitting log sample size, a significant trend for earlier laying was detected for England but not for Poland (Table 2). There was, however, no significant difference in trends between the 2 countries $\left(F_{1,49}=0.46, \mathrm{p}=0.50\right)$. Data from both countries showed a response to mean February-April temperature (Table 3) and while the response from England seemed greater, it was not significantly different $\left(F_{1,49}=0.10, \mathrm{p}=0.75\right)$ (Fig. 6).

\section{DISCUSSION AND CONCLUSIONS}

The general pattern of earlier phenology and a response to ambient temperature reported here has been found widely in both animal and plant studies (e.g. Walther et al. 2002, Parmesan \& Yohe 2003, Menzel et al. 2006), and may be because vertebrate phenology follows trends in vegetation and/or invertebrate development (Harrington et al. 1999, Walther et al. 2002) in addition to any physiological responses to 
warming (Beebee 1996, Cummins 2003, Crick 2004, Robinson et al. 2005). This study shows that populations of the same animal species, at similar latitudes and altitudes, but under different climatic regimes, can exhibit differences in the scale of phenological response to temperature. Thus, populations of the same species appear to be adapted to their climates. Despite being under the same photoperiodic conditions, populations in the UK, with a maritime climate, show earlier breeding activity and a greater response to temperature than populations adapted to a more continental climate in Poland. There is even evidence to suggest that this trend occurs between the west and east of the UK.

It is sometimes difficult to find records of the same events at similar latitudes, and we are as limited in the choice of species (and events) here as we were in the previous study on plants (Tryjanowski et al. 2006). We were unable to locate records on toad spawning at similar latitude, but we think that the use of the migration records reported here will not be misleading. Both spawning and migration responds to temperature (Beebee 1996). We have used as example species both ectothermic and endothermic animals, but it would be unwise to generalise from this small sample.

What is clear is that breeding activity gets underway earlier in the UK than in Poland for all 3 animals, and the large differences (ca. 2 mo) in the mean dates of frog spawning between Wales and Poland suggest that photoperiod can only play a minor role in this species' phenology. For the frog and toad it seems that the temperature response in Poland is much more conservative than that in the UK, as we found for 2 plants (Tryjanowski et al. 2006). Because winter temperatures are lower in Poland relative to the UK (see Table 1) this suggests that precocious behaviour in Polish animals would involve high risk, particularly in the amphibians which only have one breeding attempt per year. Birds will typically be able to lay repeat clutches if necessary, but at a physiological cost (Whitmore et al. 1977, Brown \& Brown 2000). In the case of amphibians, experiments to examine breeding behaviour of translocated individuals to confirm these findings would be an interesting follow-up study.

We suggest that animals in Poland have adapted, exhibiting conservative behaviour to deal with the local climate. What is not known is whether these species can modify their phenological response in a period of a rapidly warming climate, and if so, how quickly. This fundamental question needs urgent attention as it could undermine the conclusions of the large number of climate envelope modelling studies that have been undertaken around the world (e.g. Harrison et al. 2001) which assume a fixed relationship between climate and the distribution of a species.
Acknowledgements. We thank 2 anonymous referees for their comments on an earlier draft of this paper. We are grateful to M. Rybacki, L. Berger and J. Tęczyński for help in collecting field data on amphibians in Poland, to J. Karg for assistance with obtaining Turew temperature data, and to R. Regelous for the Kilgetty data. We are very grateful to all the volunteer birdwatchers who have contributed records to the BTO's Nest Record Scheme which is funded under the Joint Nature Conservation Committee (JNCC)/BTO partnership that the JNCC undertakes on behalf of Natural England, Scottish Natural Heritage, the Countryside Council for Wales and the Environment and Heritage Service in Northern Ireland.

\section{LITERATURE CITED}

Beebee TJC (1996) Ecology and conservation of amphibians. Chapman \& Hall, London

Brown CR, Brown MB (2000) Weather-mediated natural selection on arrival time in cliff swallows (Petrochelidon pyrrhonota). Behav Ecol Sociobiol 47:339-345

Cooke AS (1999) Changes in status of the common frog and common toad. Huntingdon Fauna Flora Soc, 50th Anniv Rev, 1948-1998:30-33

Cooke AS, Sparks TH (2004) Population declines of common toads (Bufo bufo): the contribution of road traffic and monitoring value of casualty counts. Herpetol Bull 88: $13-26$

Crick HQP (2004) The impact of climate change on birds. Ibis 146(Suppl 1):48-56

Crick HQP, Baillie SR, Leech DI (2003) The UK Nest Record Scheme: its value for science and conservation. Bird Stud 50:254-270

Croxton PJ, Huber K, Collinson N, Sparks TH (2006) How well do the Central England Temperature and England and Wales Precipitation series represent the climate of the UK? Int J Climatol 26:2287-2292

Cummins CP (2003) UV-B radiation, climate change and frogs: the importance of phenology. Ann Zool Fenn 40: 61-67

Draper NR, Smith H (1998) Applied regression analysis. Wiley, New York

Harrington R, Woiwod I, Sparks TH (1999) Climate change and trophic interactions. Trends Ecol Evol 14:146-149

Harrison PA, Berry PM, Dawson TP (eds) (2001) Climate change and nature conservation in Britain and Ireland: modelling natural resource responses to climate change (the MONARCH project). UKCIP Tech Rep, United Kingdom Climate Impacts programme, Oxford

Menzel A, Sparks TH, Estrella N, Koch E and 27 others (2006) European phenological response to climate change matches the warming pattern. Global Change Biol 12: 1969-1976

Parmesan C, Yohe G (2003) A globally coherent fingerprint of climate change impacts across natural systems. Nature 421:37-42

Rainio K, Laaksonen T, Ahola M, Vahatalo AV, Lehikoinen E (2006) Climatic responses in spring migration of boreal and arctic birds in relation to wintering area and taxonomy. J Avian Biol 37:507-515

Robinson RA, Learmonth JA, Hutson AM, Macleod CD and 5 others (2005) Climate change and migratory species. BTO Res Rep No. 414, Defra, London

Sparks TH, Roberts DR, Crick HQP (2001) What is the value of first arrival dates of spring migrants in phenology? Avian Ecol Behav 7:75-86

Tryjanowski P, Kuźniak S, Sparks T (2002) Earlier arrival of 
some farmland migrants in western Poland. Ibis 144:62-68 Tryjanowski P, Rybacki M, Sparks T (2003) Changes in the first spawning dates of common frogs and common toads in western Poland in 1978-2002. Ann Zool Fenn 40: 459-464

Tryjanowski P, Panek M, Sparks T (2006) Phenological response of plants to temperature varies at the same lati-

Editorial responsibility: Mauricio Lima,

Santiago, Chile tude: case study of dog violet and horse chestnut in England and Poland. Clim Res 32:89-93

Walther GR, Post E, Convey P, Menzel A and 5 others (2002) Ecological responses to recent climate change. Nature 416:389-395

Whitmore RC, Mosher JA, Frost HH (1977) Spring migrant mortality during unseasonable weather. Auk 94:778-781

Submitted: March 1, 2007; Accepted: May 25, 2007

Proofs received from author(s): July 10, 2007 